\title{
A review of the potential therapeutic role of statins in the treatment of Alzheimer's disease: current research and opinion
}

This article was published in the following Dove Press journal:

Neuropsychiatric Disease and Treatment

3 January 2013

Number of times this article has been viewed

\author{
Álvaro Sánchez-Ferro ${ }^{1-4}$ \\ Julián Benito-León ${ }^{1-3}$ \\ Alex J Mitchell ${ }^{5}$ \\ Félix Bermejo-Pareja ${ }^{1-3}$ \\ 'Department of Neurology, University \\ Hospital 12 de Octubre, Madrid, \\ Spain; ${ }^{2}$ Department of Medicine, \\ Complutense University, Madrid, \\ Spain; ${ }^{3}$ Centro de Investigación \\ Biomédica en Red sobre \\ Enfermedades Neurodegenerativas, \\ Madrid, Spain; ${ }^{4}$ Instituto de Salud \\ Carlos III, Madrid, Spain; ${ }^{5}$ Department \\ of Psycho-oncology, Leicestershire \\ Partnership NHS Trust and University \\ of Leicester, Leicester, UK
}

\begin{abstract}
Alzheimer's disease is one of the most prevalent neurodegenerative disorders. However, there is no current treatment, which definitively influences disease progression over a sustained period. Numerous studies linking an increase in serum cholesterol, mainly during midlife, with the pathogenic process of Alzheimer's disease have been published. Therefore, the role of statins as a therapy in this disorder may be of great interest. The aim of the present review is to summarize of the role of statins in the treatment of Alzheimer's disease.
\end{abstract}

Keywords: animal models, epidemiology, HMGCoA-inhibitors, clinical trials, prevention, cognitive function

\section{Introduction}

Dementia affects an estimated 35.6 million people worldwide. This figure will triple in the next 40 years, with 115.4 million people expected to have this diagnosis in $2050 .{ }^{1}$ The most prevalent type of dementia is Alzheimer's disease (AD), which is responsible for more than half of the cases. ${ }^{2,3} \mathrm{AD}$ is characterized by a progressive impairment of memory and other cognitive functions, ${ }^{4}$ with moderate or rapid progression in many cases. ${ }^{5}$ There is currently no effective therapy that can prevent deterioration. The combination of a high prevalence ${ }^{2,3}$ accompanied by high burden ${ }^{6}$ means that $\mathrm{AD}$ is a public health priority and the search for effective therapeutic agents a priority. ${ }^{1}$ One of these potential therapeutic strategies is the use of cholesterol reducing medication (statins), as there appears to be a link between high serum cholesterol levels and AD. ${ }^{7}$

The aim of the present review is to summarize the possible role of statins in the treatment of AD.

\section{Cholesterol and AD: the origins}

Cholesterol is a basic compound of cell membranes, modulating their fluidity and permeability. ${ }^{8}$ In the central nervous system uniquely, cholesterol is produced locally, as the blood-brain barrier effectively prevents the entrance of its circulating fraction. ${ }^{9}$

The first evidence highlighting a potential role of cholesterol in the pathological process underlying AD was based on experimental animal and cell-culture models. Additional evidence came from epidemiological studies that we will detail.

Correspondence: Julián Benito-León Avda. De la Constitución 73, portal 3, $7^{\circ}$ Izquierda, E-2882I, Coslada, Madrid, Spain

$\mathrm{Tel}+34916695467$

Fax+34913908600

Email jbenitol@meditex.es

\section{Cholesterol and the pathogenic process of AD: the amyloid hypothesis}

One of the early research studies was a clinical-pathological study of necropsy specimens from individuals with/without heart disease, where a correlation between vascular 
risk factors and the brain deposition of senile plaques containing the amyloid- $\beta(\mathrm{A} \beta)$-peptide, the putative pathologic species in AD, was found. ${ }^{10}$ Many experimental studies suggest that hypercholesterolemia accelerates the production of $\mathrm{A} \beta$-peptide by shifting amyloid precursor protein metabolism from alpha to beta cleavage products, by $\beta$ - and $\gamma$-secretases (Figure 1). ${ }^{11-13}$ These secretases are embedded in a membrane structure known as a lipid raft, with high cholesterol content. ${ }^{14}$ Cholesterol may influence this processing through the accumulation of proamyloidogenic forms that could trigger the pathogenic process of AD. ${ }^{12,15-17}$

Another type of evidence linking cholesterol and the pathogenic process of AD is that several lipoproteins involved in cholesterol metabolism are also related to amyloid deposition and AD. ${ }^{18}$ One of these lipoproteins is apolipoprotein (Apo) E, which is one of the strongest genetic risk factors known for AD. ${ }^{19}$ ApoE is a $35 \mathrm{kDa}$ glycoprotein that exists in three isoforms differing by a single amino acid. One of these is ApoE4, which is estimated to be present in 14\%-15\% of the general population ${ }^{20}$ and $37 \%-68 \%$ of patients with AD. ${ }^{21}$ Heterozygote and homozygous carriers have, respectively, a threefold and eightfold increased risk of AD. ${ }^{19,22}$ Recent attention has been directed to ApoJ (clusterin), ${ }^{23}$ another lipoprotein protractedly associated with AD, and also to the low-density lipoprotein (LDL) receptor, which is related to the synaptogenic impairment found in $\mathrm{AD} .^{24}$

The mechanism whereby serum hypercholesterolemia leads to an increased neuronal content of cholesterol is unknown, but may be mediated by some cholesterol derivatives implied in its excretion pathways, known as oxysterols. ${ }^{25}$ One of these products is 27-hydroxycholesterol (27-OHC), which is predominantly formed in the circulation and, in

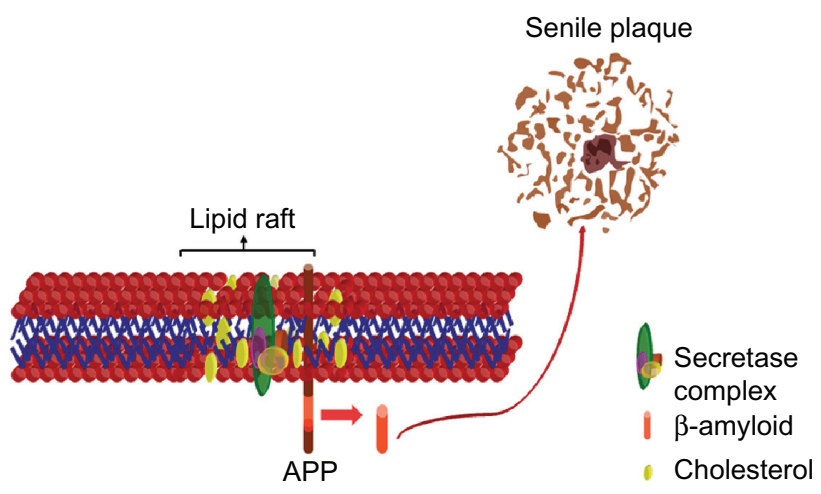

Figure I Amyloid processing by secretase and cholesterol interaction in lipid raft. Notes: Hypercholesterolemia accelerates the production of amyloid- $\beta$-peptide, triggering the process of Alzheimer's disease with the formation of amyloid aggregates (senile plaque), by shifting amyloid precursor protein metabolism from alpha to beta cleavage products by $\beta$ - and $\gamma$-secretases. These secretases are embedded in a membrane structure, known as a lipid raft, with high cholesterol content.

Abbreviation: APP, amyloid precursor protein. contrast to cholesterol, has the ability to cross into the brain. ${ }^{26}$ $27-\mathrm{OHC}$ is known to increase $\mathrm{A} \beta$ levels in both organotypic hippocampal slices and in neuronal preparations cultured from adult rabbits. ${ }^{26}$ Some authors consider therefore, that $27-\mathrm{OHC}$ is the link between circulating cholesterol and AD-like pathology in the brain. ${ }^{26}$ Opposite to $27-\mathrm{OHC}$, 24-hydroxycholesterol (24-OHC) is brain-specific and is the main mechanism for eliminating cholesterol from the brain. ${ }^{25}$ Plasma levels of 24-OHC are reduced in advanced $\mathrm{AD}$ and correlate with the degree of brain atrophy and neuronal loss. ${ }^{25}$ There is evidence of the ability of $24-\mathrm{OHC}$ to inhibit $\mathrm{A} \beta$ formation. Consequently, a reduced brain level of 24-OHC may accelerate the pathogenic process of $\mathrm{AD}{ }^{25}$

\section{Epidemiological studies linking cholesterol with $A D$}

Epidemiologic studies examining the association between cholesterol and AD have reported conflicting results. ${ }^{27}$ Among longitudinal studies, high total cholesterol has been associated with both an increased ${ }^{28,29}$ and decreased ${ }^{30-32}$ risk of $\mathrm{AD}$, as well as no effect. ${ }^{33-35}$

There are possible explanations for these conflicting results concerning cholesterol and dementia. First, such epidemiological studies could have yielded different results dependent on when cholesterol was measured (ie, midlife versus late life). In other outcomes such as cardiovascular disease, other studies have observed a similar pattern, in which high cholesterol in midlife, ${ }^{36,37}$ but not late life, ${ }^{38}$ is a risk factor. Second, an alternative explanation is that conflicting results may depend on whether cholesterol has been measured early versus late in the course of the disease process. The timing of measurements with respect to the disease process has been a factor in studies concerning the relationship between blood pressure and body mass index, and dementia. In studies with fewer than 10 years of follow up, ${ }^{39-41}$ the null or opposite relationship has been observed. In studies with more than 10 years of follow up, ${ }^{42-44}$ arterial hypertension and body mass index have been associated with an increased risk of AD. It has been hypothesized that several years before dementia begins, blood pressure and body mass index start to decline, perhaps as a result of preclinical AD pathology. ${ }^{42}$ The same process may also be involved regarding cholesterol. Indeed, a decrease in cholesterol immediately before the dementia diagnosis could also be a predictor of dementia. ${ }^{28}$ Finally, there is a possibility of mortality bias; however, this does not seem to be a likely explanation. Theoretically, hypercholesterolemic subjects may have an increased risk of mortality before dementia 
begins and therefore less chance to develop dementia than subjects with low cholesterol. However, it has been noted in other studies, such as the Neurological Diseases in Central Spain (NEDICES), ${ }^{45-48}$ that low cholesterol is also associated with mortality among the elderly (Sierra-Hidalgo and Bermejo-Pareja, unpublished data, 2012).

\section{Animal models of beta-amyloid deposition}

There are three main animal models where a link between cholesterol and AD has been established. One is a leporid exemplary (New Zealand White rabbit), used initially for coronary artery disease, where a $2 \%$ dietary intake of cholesterol induced amyloid brain deposition. ${ }^{11}$ In both transgenic amyloid precursor protein and LDL receptor knock-out mice (which mimics human hypercholesterolemia), the same influence of cholesterol on amyloid pathology has been observed. ${ }^{49,50}$ An additional model (Guinea pig) has shown indirect proof of cholesterol impact on A $\beta$-peptide after statin therapy. ${ }^{13}$

\section{Cell culture evidence of cholesterol and $A D$}

The experimental evidence linking cholesterol and AD is not limited to animal models. There are several in vitro studies in which an association between cholesterol and $A \beta$-peptide deposition has been observed. ${ }^{12,15,51}$ The proposed mechanism is an increase of $\beta$ - and $\gamma$-secretase activity that leads to increased levels of intracellular A $\beta$-peptide. By contrast, a negative impact of cholesterol lowering has been suggested by another experimental design, tangling the relationship between this lipid and the pathogenic process of AD. ${ }^{52}$

\section{Conclusions regarding the association of cholesterol and AD}

It seems likely that cholesterol has an influence on the AD pathological process, favoring $\mathrm{A} \beta$-peptide brain deposition. This is based on different experimental evidence and epidemiological studies that individuals exposed to high levels, particularly during midlife, have an increased risk of AD. This evidence constitutes, at least, a rationale for the study of statin therapy as a potential tool to prevent and/or treat AD.

\section{Statins and AD}

Different authors have previously reviewed the role of statins in $\mathrm{AD} .{ }^{53-57}$ Here we review the outcomes of the main randomized clinical trials (RCT) conducted to date and explore future treatment possibilities for these therapeutic agents.

\section{Basic concepts}

The main effects of statins are based on their lipid-lowering capacity. ${ }^{58}$ This is mediated through the inhibition of 3-hydroxy-3-methylglutaryl coenzyme A reductase (an enzyme implied in cholesterol biosynthesis), which produces a decrease in low-density lipoprotein (LDL) cholesterol. ${ }^{58}$ The effect depends on the dose and type of statin but, as an illustration, can range from a mean $1.5 \mathrm{mmol} / \mathrm{L}(59 \mathrm{mg} / \mathrm{dL})$ decline with $20 \mathrm{mg}$ simvastatin to $2.0 \mathrm{mmol} / \mathrm{L}(77 \mathrm{mg} / \mathrm{dL})$ with $40 \mathrm{mg}$ atorvastatin or even greater for higher doses or different agents. ${ }^{58}$

Although the lipid-lowering effect of statins has been the main feature addressed in $\mathrm{AD}$, this is not the only potentially beneficial mechanism. Other recognized pleiotropic effects of statins are their anti-inflammatory and antiendothelial dysfunction activity, as well as their antioxidant, profibrinolytic, or antiproliferative properties. ${ }^{59,60} \mathrm{~A}$ distinction is made between the lipophilicity and the chemical structure of the different statins, as this influences their ability to cross the blood-brain barrier. ${ }^{60,61}$ Gathering these characteristics with the different hypocholesterolemic activity they may exert in neurons could be an explanation for the lack of effect found by some RCTs that used statins with low potential to influence the brain cholesterol content. ${ }^{62}$ In a recent study, simvastatin was found to be the most efficient statin, considering all these features. ${ }^{61}$

\section{Preliminary evidence revealing a protective effect of statins on AD}

The first reports suggesting a potential therapeutic effect of statins were based on two independent observational studies in which a decreased risk of $\mathrm{AD}$ was found for the exposed group. ${ }^{56,63}$ In a nested case-control design with information derived from 368 practices in the UK-based General Practice Research Database, the adjusted relative risk of dementia for those who were prescribed statins was $0.29(0.13-0.63 ; P=0.002) .{ }^{63}$ In a cross-sectional analysis comparing the prevalence of probable AD in three groups of patients (the entire population, patients receiving statins, and patients receiving medications used to treat hypertension or cardiovascular disease) from hospital records, the prevalence of probable $\mathrm{AD}$ in the cohort taking statins over 23 months was $60 \%-73 \%(P<0.001)$ lower than in the total patient population and lower than in those patients taking other medications typically used in the treatment of hypertension or cardiovascular disease. ${ }^{56}$ After these initial reports, some other observational studies have yielded conflicting results with the great majority supporting this initial evidence, even 
in predementia subjects $;{ }^{64-71}$ whilst others have failed to show any differences. ${ }^{72-74}$

\section{Main interventional trials}

Preventive and therapeutic trials have tried to address the effects of statins on cognitive function. ${ }^{57,62}$ In two large studies (Table 1), the neuroprotective effect on cognitive function was assessed as a secondary outcome. ${ }^{75,76}$ Both failed to show any improvement for the treated subjects. ${ }^{75,76}$ The enrolled patients had no overt cognitive impairment at baseline and had cardiovascular risk factors, including high cholesterol level. They received placebo or either $40 \mathrm{mg}$ pravastatin with a mean 3.2-year follow-up ${ }^{75}$ or $40 \mathrm{mg}$ simvastatin, with a 5 -year mean follow-up. ${ }^{76}$ No differences were found in cognitive outcomes. Similarly, other studies have found no global effect on cognition. ${ }^{77-83}$

Other trials ${ }^{84-89}$ are also summarized in Table 1. Several showed some kind of improvement in the treated groups. One of these was based on a secondary analysis of the main study and focused on the preventive efficacy of nonsteroidal anti-inflammatory drugs in $\mathrm{AD}$, and it suggested a preventive effect, reducing AD incidence (67\% hazard risk reduction) in the 2528 normal elderly subjects studied and decreasing the worsening of neuropsychological measures (Mini-Mental State Examination) in a subset of mild cognitive impairment patients. ${ }^{84,85}$ Carlsson et al ${ }^{86}$ conducted a study in a population with an incremented risk of AD (siblings of diagnosed patients) and found a slight improvement in some neuropsychological tasks (verbal fluency and working memory) but no effect on cerebrospinal fluid amyloid (42 fraction). Some additional small studies found some beneficial effects on cognition in statins users. ${ }^{90-92}$ In the DALI study, ${ }^{90,92}$ a $24 \%$ improvement in a verbal memory test was observed in a group of diabetic patients treated with atorvastatin for 30 weeks. In another study, ${ }^{91} 49$ patients receiving $10 \mathrm{mg}$ atorvastatin for a cardiovascular indication showed statistically relevant differences, compared with the placebo group, in the performance of different cognitive tests.

The therapeutic potential of statins in AD patients with an established diagnosis has been addressed in several RCTs (Table 2). ${ }^{93-97}$ Simons et al ${ }^{93}$ performed a small study of AD patients who were diagnosed according to National Institute of Neurological and Communicative Diseases and Stroke/ Alzheimer's Disease and Related Disorders Association

Table I Preventive activity of statins on cognitive impairment

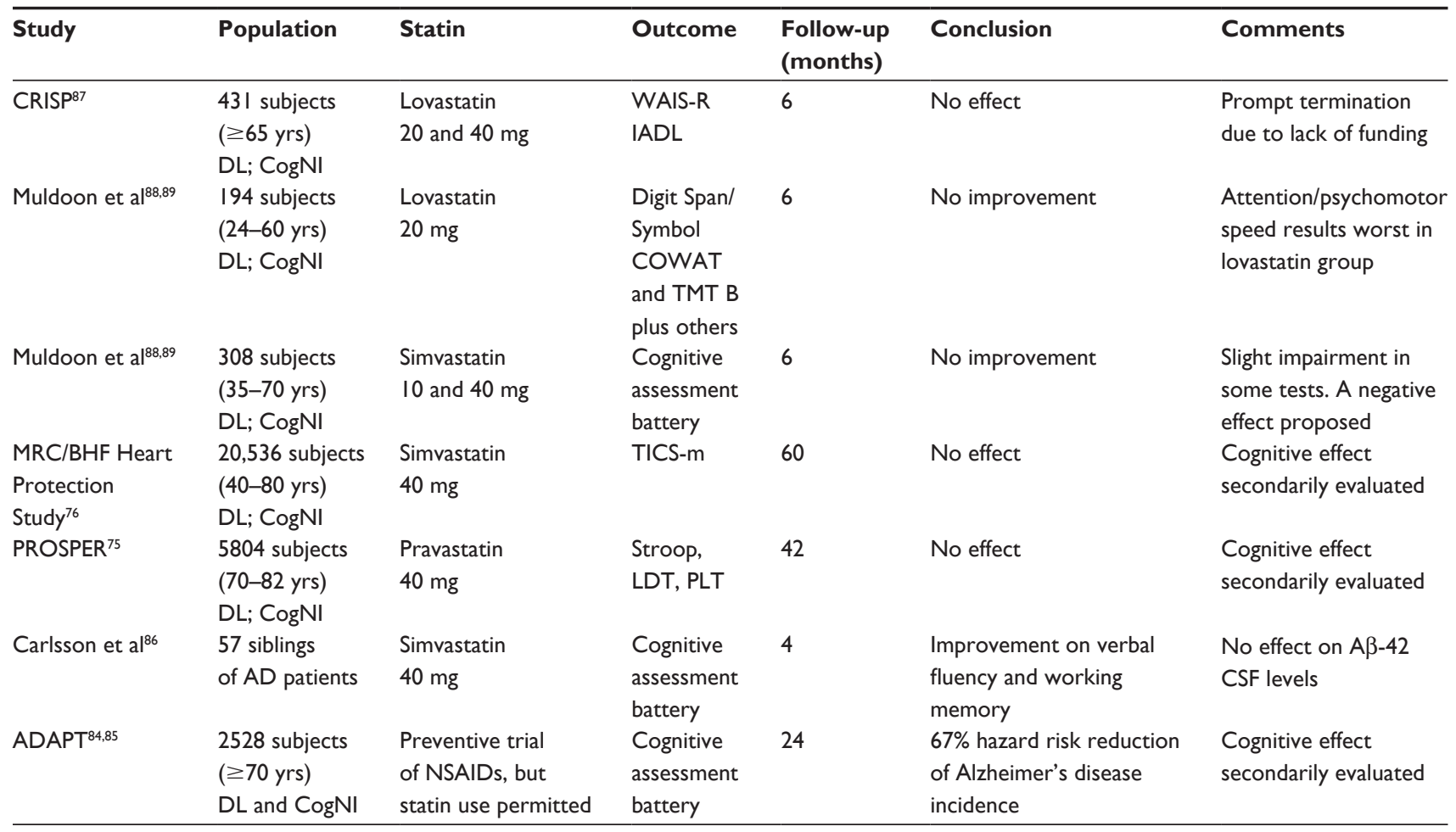

Note: Main interventional trials.

Abbreviations: DL, dyslipidemic; CogNI, cognitively not impaired; WAIS-R, Wechsler Adult Intelligence Scale-R; IADL, Instrumental Activities of Daily Living scale; COWAT, Controlled Oral Word Association; TMT B, Trail Making Test section B; TICS-m, modified Telephone Interview for Cognitive status; LDT, Letter-Digit Coding Test; PLT, I5-Picture Learning Test; AD, Alzheimer's disease; A $\beta-42$, amyloid-beta 42 fraction; CSF, cerebrospinal fluid; NSAIDs, non-steroidal-anti-inflammatory drugs. 
Table 2 Statins and Alzheimer's disease

\begin{tabular}{|c|c|c|c|c|c|c|}
\hline $\begin{array}{l}\text { Study/ } \\
\text { Clinical Trial } \\
\text { Number* }\end{array}$ & Population & Statin & Outcome & $\begin{array}{l}\text { Follow-up } \\
\text { (months) }\end{array}$ & Conclusion & Comments \\
\hline $\begin{array}{l}\text { ADCLT/ } \\
\text { NCT0002453 I 96,97,105 }\end{array}$ & $\begin{array}{l}67 \text { patients (mild to } \\
\text { moderate } A D \text { ) } \\
\geq 51 \text { yrs (mean 78.2) }\end{array}$ & $\begin{array}{l}\text { Atorvastatin } \\
80 \mathrm{mg}\end{array}$ & $\begin{array}{l}\text { ADAS-Cog, } \\
\text { MMSE, CGIC }\end{array}$ & 12 & $\begin{array}{l}\text { Fewer declines in } \\
\text { ADAS-cog at } 6 \text { month }\end{array}$ & $\begin{array}{l}\text { Six subjects in } \\
\text { atorvastatin group } \\
\text { and ten in placebo } \\
\text { group were lost to } \\
\text { follow-up }\end{array}$ \\
\hline $\begin{array}{l}\text { LEADe/ } \\
\text { NCT00I } 5 \text { I 50294,106 }\end{array}$ & $\begin{array}{l}640 \text { patients (mild to } \\
\text { moderate } A D \text { ) } \\
\geq 51 \text { yrs (mean } 78.2 \text { ) }\end{array}$ & $\begin{array}{l}\text { Atorvastatin } \\
80 \mathrm{mg}\end{array}$ & $\begin{array}{l}\text { ADAS-Cog, } \\
\text { MMSE, CGIC; } \\
\text { NPI, CDR-B }\end{array}$ & 18 & No effect & $\begin{array}{l}\text { Normolipemic } \\
\text { subjects }\end{array}$ \\
\hline Simons et $\mathrm{al}^{93}$ & $\begin{array}{l}44 \text { patients (mild to } \\
\text { moderate AD) } \\
>60 \text { yrs (mean 68.0) }\end{array}$ & $\begin{array}{l}\text { Simvastatin } \\
80 \mathrm{mg}\end{array}$ & $\begin{array}{l}\text { MMSE, ADAS- } \\
\text { Cog, CSF A } \beta\end{array}$ & 6.5 & $\begin{array}{l}\text { Better MMSE } \\
\text { performance/augmented } \\
\text { A } \beta 40\end{array}$ & $\begin{array}{l}\text { Showed less effect } \\
\text { than the experimental } \\
\text { model studied by the } \\
\text { group }\end{array}$ \\
\hline $\begin{array}{l}\text { Sano et al/ } \\
\text { NCT0005359995,107 }\end{array}$ & $\begin{array}{l}406 \text { subjects (mild to } \\
\text { moderate } A D \text { ) } \\
>50 \text { yrs (mean } 74.6 \text { ) }\end{array}$ & $\begin{array}{l}\text { Simvastatin } \\
40 \mathrm{mg}\end{array}$ & $\begin{array}{l}\text { ADAS-Cog, } \\
\text { MMSE, NPI, } \\
\text { and others }\end{array}$ & 18 & No effect & $\begin{array}{l}\text { Normolipemic } \\
\text { subjects }\end{array}$ \\
\hline
\end{tabular}

Notes: Main interventional trials. *Clinical Trial Numbers are based on Burgos et al ${ }^{57}$ and at http://ClinicalTrials.gov/.

Abbreviations: AD, Alzheimer's Disease; ADAS-Cog, Alzheimer's Disease Assessment Scale-Cognitive subscale; ADCLT, Alzheimer's Disease Cholesterol-Lowering Treatment trial; MMSE, Mini-Mental State Examination; CGIC, Clinical Global Impression of Change; NPI, Neuropsychiatric Inventory; CDR-SB, Clinical Dementia Rating-Sum of Boxes; CSF, cerebrospinal fluid; $A \beta$, amyloid-beta.

(NINCDS/ADRDA) criteria and randomly allocated to $80 \mathrm{mg}$ simvastatin or placebo for a 26 -week period. There was a significant effect on cognitive performance as well as an improvement in the $A \beta-40$ cerebrospinal fluid levels of the treated group. ${ }^{93}$ Since this preliminary study, three other RCTs have been published. ${ }^{94-97}$ The largest one included normolipemic $\mathrm{AD}$ patients who were randomly treated with atorvastatin $80 \mathrm{mg}$ or placebo and assessed at 3-month intervals during 18 months. ${ }^{94}$ No differences in the cognitive performance of the treated group were found; however, some marginal differences in the hippocampal-MRI assessment were detected ${ }^{94}$ Sparks et a ${ }^{96,97}$ found modest differences in Alzheimer's Disease Assessment Scale-Cognitive subscale (ADAS)-Cog performance at the 6-month follow-up but not at 12 months, in a small group of AD patients randomly assigned to $80 \mathrm{mg}$ atorvastatin. Sano et $\mathrm{a}^{95}$ conducted a large RCT of 406 subjects with mild to moderate AD that failed to show any difference in the cognitive performance of patients taking simvastatin $40 \mathrm{mg}$ versus placebo, incorporating an 18-month follow-up.

Since the larger trials have failed to show sustainable differences in cognitive performance or $\mathrm{AD}$ risk in the populations evaluated, the evidence suggests negligible benefit of statins at the current time. Some modest differences in subsets of patients might warrant further exploration. Another possibility that we will briefly comment on, are the methodological caveats that could influence the assessment of statin activity in $\mathrm{AD}$. These could be an explanation for this inconclusive evidence, and several authors have highlighted this in the referred trials. ${ }^{62}$

\section{Potential reasons for the lack of correlation between experimental evidences and therapeutic outcomes}

Major concerns with statin research are the methodological issues that could influence the results. This is particularly important for the observational studies, where the lack of randomization introduces potential bias, commonly observed among statins users. Two of the most recognized are "indication bias" (in which a drug is prescribed to treat a condition that is associated with the variable of interest) and "cessation bias" (where some of the observed protective effects of a drug may be due to patients stopping the drug therapy after being diagnosed as having a condition). ${ }^{98}$

It has been also suggested that cohorts of statin users could be a selected population with a better-than-average health status, implying a decreased risk of AD. Alternatively, they could have worse health status and reduce the risk of AD through unrelated mortality. Other design issues could be related to the type, dose, and blood-brain barrier-crossing ability of the prescribed statin, as well as other pleiotropic effects, different from their lipid-lowering ability, which are not usually evaluated. ${ }^{57,62}$ An additional possibility for the lack of homogeneous effect observed, supported by some groups, is that statins may themselves have a negative impact on cognition. This has been suggested by some observational studies, ${ }^{99-101}$ and another 
population-based analysis. ${ }^{102}$ Also, one RCT found worse performance in cognitive testing, but it was not designed for this purpose. ${ }^{88}$ This topic has been reviewed recently, especially after the Food and Drug Administration warning about this potential adverse outcome. The evidence so far, nonetheless, has been deemed inconclusive. ${ }^{103,104}$

\section{Summary}

Although a potential role of cholesterol in the pathogenic process of AD has been established through different experimental models, statin therapy has failed to show a clear general effect on the treatment or the prevention of this disease. In addition, we suggest future RCTs should test the use of statins with biomarkers, like amyloid (positron emission tomography [PET] tracers or cerebrospinal fluid levels) and others, as this is the main sustention of the bonds between cholesterol, and hence statins, and the AD pathological process. Upcoming studies should also consider all the methodological caveats reported so far. This could ensure that the target population at risk (midlife cholesterol exposure) is replicated and the appropriate product (statins with capability of influencing brain-cholesterol content) used.

\section{Disclosure}

The authors report no conflicts of interest in this work.

\section{References}

1. World Health Organization. Dementia: A Public Health Priority. Geneva: World Health Organization; 2012. Available from: http://whqlibdoc. who. int/publications/2012/9789241564458_eng.pdf. Accessed November 9, 2012.

2. Bermejo-Pareja F, Benito-Léon J, Vega S, Medrano MJ, Román GC; Neurological Disorders in Central Spain (NEDICES) Study Group. Incidence and subtypes of dementia in three elderly populations of central Spain. J Neurol Sci. 2008;264(1-2):63-72.

3. Bermejo-Pareja F, Benito-Léon J, Vega S, et al. Consistency of clinical diagnosis of dementia in NEDICES: A population-based longitudinal study in Spain. J Geriatr Psychiatry Neurol. 2009;22(4):246-255.

4. McKhann G, Drachman D, Folstein M, Katzman R, Price D, Stadlan EM. Clinical diagnosis of Alzheimer's disease: report of the NINCDSADRDA Work Group under the auspices of Department of Health and Human Services Task Force on Alzheimer's Disease. Neurology. 1984;34(7):939-944.

5. Villarejo A, Benito-Léon J, Trincado R, et al. Dementia-associated mortality at thirteen years in the NEDICES Cohort Study. J Alzheimers Dis. 2011;26(3):543-551.

6. Rivera J, Bermejo F, Franco M, Morales-González JM, Benito-Léon J. Understanding care of people with dementia in Spain: cohabitation arrangements, rotation and rejection to long term care institution. Int $J$ Geriatr Psychiatry. 2009;24(2):142-148.

7. Anstey KJ, Lipnicki DM, Low LF. Cholesterol as a risk factor for dementia and cognitive decline: a systematic review of prospective studies with meta-analysis. Am J Geriatr Psychiatry. 2008;16(5):343-354.

8. Grimm MO, Tschäpe JA, Grimm HS, Zinser EG, Hartmann T. Altered membrane fluidity and lipid raft composition in presenilin-deficient cells. Acta Neurol Scand Suppl. 2006;185:S27-S32.
9. Lütjohann D. Cholesterol metabolism in the brain: importance of 24Shydroxylation. Acta Neurol Scand Suppl. 2006;185:S33-S42.

10. Sparks DL, Hunsaker JC 3rd, Scheff SW, Kryscio RJ, Henson JL, Markesbery WR. Cortical senile plaques in coronary artery disease, aging and Alzheimer's disease. Neurobiol Aging. 1990;11(6):601-607.

11. Sparks DL, Scheff SW, Hunsaker JC 3rd, Liu H, Landers T, Gross DR. Induction of Alzheimer-like beta-amyloid immunoreactivity in the brains of rabbits with dietary cholesterol. Exp Neurol. 1994;126(1):88-94.

12. Simons M, Keller P, De Strooper B, Beyreuther K, Dotti CG, Simons K. Cholesterol depletion inhibits the generation of beta-amyloid in hippocampal neurons. Proc Natl Acad Sci U S A. 1998;95(11): 6460-6464

13. Fassbender K, Simons M, Bergmann C, et al. Simvastatin strongly reduces levels of Alzheimer's disease beta-amyloid peptides Abeta 42 and Abeta 40 in vitro and in vivo. Proc Natl Acad Sci U SA. 2001;98(10): $5856-5861$.

14. Simons K, Ehehalt R. Cholesterol, lipid rafts, and disease. J Clin Invest. 2002;110(5):597-603.

15. Bodovitz S, Klein WL. Cholesterol modulates alpha-secretase cleavage of amyloid precursor protein. J Biol Chem. 1996;271(8):4436-4440.

16. Rösler M, Anand R, Cicin-Sain A, et al. Efficacy and safety of rivastigmine in patients with Alzheimer's disease: international randomised controlled trial. BMJ. 1999;318(7184):633-638.

17. Pappolla MA, Bryant-Thomas TK, Herbert D, et al. Mild hypercholesterolemia is an early risk factor for the development of Alzheimer amyloid pathology. Neurology. 2003;61(2):199-205.

18. Reiss AB, Voloshyna I. Regulation of cerebral cholesterol metabolism in Alzheimer disease. J Investig Med. 2012;60(3):576-582.

19. Corder EH, Saunders AM, Strittmatter WJ, et al. Gene dose of apolipoprotein E type 4 allele and the risk of Alzheimer's disease in late onset families. Science. 1993;261(5123):921-923.

20. Schipper HM. Apolipoprotein E: implications for AD neurobiology, epidemiology and risk assessment. Neurobiol Aging. 2011; 32(5):778-790.

21. Crean S, Ward A, Mercaldi CJ, et al. Apolipoprotein E $\varepsilon 4$ prevalence in Alzheimer's disease patients varies across global populations: a systematic literature review and meta-analysis. Dement Geriatr Cogn Disord. 2011;31(1):20-30.

22. Farrer LA, Cupples LA, Haines JL, et al. Effects of age, sex, and ethnicity on the association between apolipoprotein E genotype and Alzheimer disease. A meta-analysis. APOE and Alzheimer Disease Meta Analysis Consortium. JAMA. 1997;278(16):1349-1356.

23. Nuutinen T, Suuronen T, Kauppinen A, Salminen A. Clusterin: a forgotten player in Alzheimer's disease. Brain Res Rev. 2009;61(2):89-104.

24. Herz J, Chen Y. Reelin, lipoprotein receptors and synaptic plasticity. Nat Rev Neurosci. 2006;7(11):850-859.

25. Björkhem I, Heverin M, Leoni V, Meaney S, Diczfalusy U. Oxysterols and Alzheimer's disease. Acta Neurol Scand Suppl. 2006;185: S43-S49.

26. Ghribi O. Potential mechanisms linking cholesterol to Alzheimer's disease-like pathology in rabbit brain, hippocampal organotypic slices, and skeletal muscle. J Alzheimers Dis. 2008;15(4):673-684.

27. Shepardson NE, Shankar GM, Selkoe DJ. Cholesterol level and statin use in Alzheimer disease: I. Review of epidemiological and preclinical studies. Arch Neurol. 2011;68(10):1239-1244.

28. Notkola IL, Sulkava R, Pekkanen J, et al. Serum total cholesterol, apolipoprotein E epsilon 4 allele, and Alzheimer's disease. Neuroepidemiology. 1998;17(1):14-20.

29. Kivipelto M, Helkala EL, Laakso MP, et al. Midlife vascular risk factors and Alzheimer's disease in later life: longitudinal, population based study. BMJ. 2001;322(7300):1447-1451.

30. Romas SN, Tang MX, Berglund L, Mayeux R. APOE genotype, plasma lipids, lipoproteins, and $\mathrm{AD}$ in community elderly. Neurology. 1999;53(3):517-521.

31. Reitz C, Tang MX, Luchsinger J, Mayeux R. Relation of plasma lipids to Alzheimer disease and vascular dementia. Arch Neurol. 2004;61(5):705-714. 
32. Mielke MM, Zandi PP, Sjögren M, et al. High total cholesterol levels in late life associated with a reduced risk of dementia. Neurology. 2005;64(10):1689-1695.

33. Yoshitake T, Kiyohara Y, Kato I, et al. Incidence and risk factors of vascular dementia and Alzheimer's disease in a defined elderly Japanese population: the Hisayama Study. Neurology. 1995;45(6):1161-1168.

34. Kalmijn S, Foley D, White L, et al. Metabolic cardiovascular syndrome and risk of dementia in Japanese-American elderly men. The Honolulu-Asia aging study. Arterioscler Thromb Vasc Biol. 2000;20(10):2255-2260.

35. Tan ZS, Seshadri S, Beiser A, et al. Plasma total cholesterol level as a risk factor for Alzheimer disease: the Framingham Study. Arch Intern Med. 2003;163(9):1053-1057.

36. Martin MJ, Hulley SB, Browner WS, Kuller LH, Wentworth D. Serum cholesterol, blood pressure, and mortality: implications from a cohort of 361,662 men. Lancet. 1986;2(8513):933-936.

37. Klag MJ, Ford DE, Mead LA, et al. Serum cholesterol in young men and subsequent cardiovascular disease. $N$ Engl J Med. 1993;328(5):313-318.

38. Kronmal RA, Cain KC, Ye Z, Omenn GS. Total serum cholesterol levels and mortality risk as a function of age. A report based on the Framingham data. Arch Intern Med. 1993;153(9):1065-1073.

39. Barrett-Connor E, Edelstein SL, Corey-Bloom J, Wiederholt WC Weight loss precedes dementia in community-dwelling older adults J Am Geriatr Soc. 1996;44(10):1147-1152.

40. Tsolaki M, Fountoulakis K, Chantzi E, Kazis A. Risk factors for clinically diagnosed Alzheimer's disease: a case-control study of a Greek population. Int Psychogeriatr. 1997;9(3):327-341.

41. Morris MC, Scherr PA, Hebert LE, Glynn RJ, Bennett DA, Evans DA. Association of incident Alzheimer disease and blood pressure measured from 13 years before to 2 years after diagnosis in a large community study. Arch Neurol. 2001;58(10):1640-1646.

42. Skoog I, Lernfelt B, Landahl S, et al. 15-year longitudinal study of blood pressure and dementia. Lancet. 1996;347(9009):1141-1145.

43. Gustafson D, Rothenberg E, Blennow K, Steen B, Skoog I. An 18-year follow-up of overweight and risk of Alzheimer disease. Arch Intern Med. 2003;163(13):1524-1528.

44. Launer LJ, Ross GW, Petrovitch H, et al. Midlife blood pressure and dementia: the Honolulu-Asia aging study. Neurobiol Aging. 2000;21(1):49-55.

45. Bermejo-Pareja F, Benito-Léon J, Vega QS, et al. The NEDICES cohort of the elderly. Methodology and main neurological findings. Rev Neurol. 2008;46(7):416-423. Spanish.

46. Vega S, Benito-Léon J, Bermejo-Pareja F, et al. Several factors influenced attrition in a population-based elderly cohort: neurological disorders in Central Spain Study. J Clin Epidemiol. 2010;63(2):215-222.

47. Morales JM, Bermejo FP, Benito-Léon J, et al; NEDICES Study Group. Methods and demographic findings of the baseline survey of the NEDICES cohort: a door-to-door survey of neurological disorders in three communities from Central Spain. Public Health. 2004;118(6):426-433.

48. Benito-Léon J, Louis ED, Rivera-Navarro J, Medrano MJ, Vega S, Bermejo-Pareja F. Low morale is associated with increased risk of mortality in the elderly: a population-based prospective study (NEDICES). Age Ageing. 2010;39(3):366-373.

49. Refolo LM, Pappolla MA, LaFrancois J, et al. A cholesterol-lowering drug reduces beta-amyloid pathology in a transgenic mouse model of Alzheimer's disease. Neurobiol Dis. 2001;8(5):890-899.

50. Ramírez C, Sierra S, Tercero I, et al. ApoB100/LDLR-/- hypercholesterolaemic mice as a model for mild cognitive impairment and neuronal damage. PLoS One. 2010;6(7):e22712.

51. Mizuno T, Nakata M, Naiki H, et al. Cholesterol-dependent generation of a seeding amyloid beta-protein in cell culture. J Biol Chem. 1999;274(21):15110-15114.

52. Michikawa M, Yanagisawa K. Inhibition of cholesterol production but not of nonsterol isoprenoid products induces neuronal cell death. J Neurochem. 1999;72(6):2278-2285.
53. Sparks DL. Alzheimer disease: statins in the treatment of Alzheimer disease. Nat Rev Neurol. 2011;7(12):662-663.

54. McGuinness B, Craig D, Bullock R, Passmore P. Statins for the prevention of dementia. Cochrane Database Syst Rev. 2009;15(2): CD003160.

55. McGuinness B, O’Hare J, Craig D, Bullock R, Malouf R, Passmore P. Statins for the treatment of dementia. Cochrane Database Syst Rev. 2010;4(8):CD007514.

56. Wolozin B, Kellman W, Ruosseau P, Celesia GG, Siegel G. Decreased prevalence of Alzheimer disease associated with 3-hydroxy-3methyglutaryl coenzyme A reductase inhibitors. Arch Neurol. 2000;57(10):1439-1443

57. Burgos J, Benavides J, Douillet P, Velasco J, Valdivieso F. How statins could be evaluated successfully in clinical trials for Alzheimer's disease? Am J Alzheimer Dis Other Demen. 2012;27(3):151-153.

58. Law MR, Wald NJ, Rudnicka AR. Quantifying effect of statins on low density lipoprotein cholesterol, ischaemic heart disease, and stroke: systematic review and meta-analysis. BMJ. 2003;326(7404):1423.

59. Crisby M. The role of pleiotropic effects of statins in dementia. Acta Neurol Scand Suppl. 2006;185:S115-S118.

60. Butterfield DA, Barone E, Mancuso C. Cholesterol-independent neuroprotective and neurotoxic activities of statins: perspectives for statin use in Alzheimer disease and other age-related neurodegenerative disorders. Pharmacol Res. 2011;64(3):180-186.

61. Sierra S, Ramos MC, Molina P, Esteo C, Vázquez JA, Burgos JS. Statins as neuroprotectants: a comparative in vitro study of lipophilicity, blood-brain-barrier penetration, lowering of brain cholesterol, and decrease of neuron cell death. J Alzheimers Dis. 2011;23(2): 307-318.

62. Shepardson NE, Shankar GM, Selkoe DJ. Cholesterol level and statin use in Alzheimer disease: II. Review of human trials and recommendations. Arch Neurol. 2011;68(11):1385-1392.

63. Jick H, Zornberg GL, Jick SS, Seshadri S, Drachman DA. Statins and the risk of dementia. Lancet. 2000;356(9242):1627-1631.

64. Hajjar I, Schumpert J, Hirth V, Wieland D, Eleazer GP. The impact of the use of statins on the prevalence of dementia and the progression of cognitive impairment. J Gerontol A Biol Sci Med Sci. 2002;57(7):M414-M418.

65. Rodriguez EG, Dodge HH, Birzescu MA, Stoehr GP, Ganguli M. Use of lipid-lowering drugs in older adults with and without dementia: a community-based epidemiological study. J Am Geriatr Soc. 2002; 50(11):1852-1856.

66. Yaffe K, Barrett-Connor E, Lin F, Grady D. Serum lipoprotein levels, statin use, and cognitive function in older women. Arch Neurol. 2002;59(3):378-384.

67. Zamrini E, McGwin G, Roseman JM. Association between statin use and Alzheimer's disease. Neuroepidemiology. 2004;23(1-2):94-98.

68. Rea TD, Breitner JC, Psaty BM, et al. Statin use and the risk of incident dementia: the Cardiovascular Health Study. Arch Neurol. 2005;62(7):1047-1051.

69. Dufouil C, Richard F, Fiévet N, et al. APOE genotype, cholesterol level, lipid-lowering treatment, and dementia: the Three-City Study. Neurology. 2005;64(9):1531-1538.

70. Cramer C, Haan MN, Galea S, Langa KM, Kalbfleisch JD. Use of statins and incidence of dementia and cognitive impairment without dementia in a cohort study. Neurology. 2008;71(5):344-350.

71. Haag MD, Hofman A, Koudstaal PJ, Stricker BH, Breteler MM. Statins are associated with a reduced risk of Alzheimer disease regardless of lipophilicity. The Rotterdam Study. J Neurol Neurosurg Psychiatry. 2009;80(1):13-17.

72. Zandi PP, Sparks DL, Khachaturian AS, et al; Cache County Study Investigators. Do statins reduce risk of incident dementia and Alzheimer disease? The Cache County Study. Arch Gen Psychiatry. 2005;62(2):217-224.

73. Arvanitakis Z, Schneider JA, Wilson RS, et al. Statins, incident Alzheimer disease, change in cognitive function, and neuropathology. Neurology. 2008;70(19 Pt 2):1795-1802. 
74. Benito-Léon J, Louis ED, Vega S, Bermejo-Pareja F. Statins and cognitive functioning in the elderly: a population-based study. J Alzheimers Dis. 2010;21(1):95-102.

75. Trompet $\mathrm{S}$, van Vliet $\mathrm{P}$, de Craen AJ, et al. Pravastatin and cognitive function in the elderly. Results of the PROSPER study. $J$ Neurol. 2010;257(1):85-90.

76. Heart Protection Study Collaborative Group. MRC/BHF Heart Protection Study of cholesterol lowering with simvastatin in 20,536 high-risk individuals: a randomised placebo-controlled trial. Lancet. 2002;360(9326):7-22.

77. Harrison RW, Ashton CH. Do cholesterol-lowering agents affect brain activity? A comparison of simvastatin, pravastatin, and placebo in healthy volunteers. Br J Clin Pharmacol. 1994;37(3):231-236.

78. Kostis JB, Rosen RC, Wilson AC. Central nervous system effects of HMG CoA reductase inhibitors: lovastatin and pravastatin on sleep and cognitive performance in patients with hypercholesterolemia. $J$ Clin Pharmacol. 1994;34(10):989-996.

79. Cutler N, Sramek J, Veroff A, Block G, Stauffer L, Lines C. Effects of treatment with simvastatin and pravastatin on cognitive function in patients with hypercholesterolaemia. Br J Clin Pharmacol. 1995;39(3):333-336.

80. Gengo F, Cwudzinski D, Kinkel P, Block G, Stauffer L, Lines C. Effects of treatment with lovastatin and pravastatin on daytime cognitive performance. Clin Cardiol. 1995;18(4):209-214.

81. Gibellato MG, Moore JL, Selby K, Bower EA. Effects of lovastatin and pravastatin on cognitive function in military aircrew. Aviat Space Environ Med. 2001;72(9):805-812.

82. Golomb BA, Criqui MH, White HL, Dimsdale JE. The UCSD Statin Study: a randomized controlled trial assessing the impact of statins on selected noncardiac outcomes. Control Clin Trials. 2004;25(2):178-202.

83. Summers MJ, Oliver KR, Coombes JS, Fassett RG. Effect of atorvastatin on cognitive function in patients from the Lipid Lowering and Onset of Renal Disease (LORD) trial. Pharmacotherapy. 2007;27(2):183-190.

84. Sparks DL, Kryscio RJ, Connor DJ, et al. Cholesterol and cognitive performance in normal controls and the influence of elective statin use after conversion to mild cognitive impairment: results in a clinical trial cohort. Neurodegener Dis. 2010;7(1-3):183-186.

85. Sparks DL, Kryscio RJ, Sabbagh MN, Connor DJ, Sparks LM, Liebsack C. Reduced risk of incident $\mathrm{AD}$ with elective statin use in a clinical trial cohort. Curr Alzheimer Res. 2008;5(4):416-421.

86. Carlsson CM, Gleason CE, Hess TM, et al. Effects of simvastatin on cerebrospinal fluid biomarkers and cognition in middle-aged adults at risk for Alzheimer's disease. J Alzheimers Dis. 2008;13(2):187-197.

87. Santanello NC, Barber BL, Applegate WB, et al. Effect of pharmacologic lipid lowering on health-related quality of life in older persons: results from the Cholesterol Reduction in Seniors Program (CRISP) Pilot Study. J Am Geriatr Soc. 1997;45(1):8-14.

88. Muldoon MF, Barger SD, Ryan CM, et al. Effects of lovastatin on cognitive function and psychological well-being. Am J Med. 2000; 108(7):538-546

89. Muldoon MF, Ryan CM, Sereika SM, Flory JD, Manuck SB. Randomized trial of the effects of simvastatin on cognitive functioning in hypercholesterolemic adults. Am J Med. 2004;117(11):823-829.

90. Berk-Planken I, de Konig I, Stolk R, Jansen H, Hoogerbrugge N. Atorvastatin, diabetic dyslipidemia, and cognitive functioning. Diabetes Care. 2002;25(7):1250-1251.

91. Parale GP, Baheti NN, Kulkarni PM, Panchal NV. Effects of atorvastatin on higher functions. Eur J Clin Pharmacol. 2006;62(4):259-265.

92. Diabetes Atorvastin Lipid Intervention (DALI) Study Group. The effect of aggressive versus standard lipid lowering by atorvastatin on diabetic dyslipidemia: the DALI study: a double-blind, randomized, placebo-controlled trial in patients with type 2 diabetes and diabetic dyslipidemia. Diabetes Care. 2001;24(8):1335-1341.
93. Simons M, Schwärzler F, Lütjohann D, et al. Treatment with simvastatin in normocholesterolemic patients with Alzheimer's disease: A 26-week randomized, placebo-controlled, double-blind trial. Ann Neurol. 2002;52(3):346-350.

94. Feldman HH, Doody RS, Kivipelto M, et al; LEADe Investigators. Randomized controlled trial of atorvastatin in mild to moderate Alzheimer disease: LEADe. Neurology. 2010;74(12):956-964.

95. Sano M, Bell KL, Galasko D, et al. A randomized, double-blind, placebo-controlled trial of simvastatin to treat Alzheimer disease. Neurology. 2011;77(6):556-563.

96. Sparks DL, Connor DJ, Sabbagh MN, Petersen RB, Lopez J, Browne P. Circulating cholesterol levels, apolipoprotein E genotype and dementia severity influence the benefit of atorvastatin treatment in Alzheimer's disease: results of the Alzheimer's Disease CholesterolLowering Treatment (ADCLT) trial. Acta Neurol Scand Suppl. 2006;185:S3-S7.

97. Sparks DL, Sabbagh MN, Connor DJ, et al. Atorvastatin for the treatment of mild to moderate Alzheimer disease: preliminary results. Arch Neurol. 2005;62(5):753-757.

98. Rockwood K, Kirkland S, Hogan DB, et al. Use of lipid-lowering agents, indication bias, and the risk of dementia in communitydwelling elderly people. Arch Neurol. 2002;59(2):223-227.

99. Redelmeier DA, Thiruchelvam D, Daneman N. Delirium after elective surgery among elderly patients taking statins. CMAJ. 2008;179(7): 645-652.

100. Evans MA, Golomb BA. Statin-associated adverse cognitive effects: survey results from 171 patients. Pharmacotherapy. 2009; 29(7):800-811.

101. Agostini JV, Tinetti ME, Han L, McAvay G, Foody JM, Concato J. Effects of statin use on muscle strength, cognition, and depressive symptoms in older adults. J Am Geriatr Soc. 2007;55(3):420-425.

102. Glasser SP, Wadley V, Judd S, et al. The association of statin use and statin type and cognitive performance: analysis of the reasons for geographic and racial differences in stroke (REGARDS) study. Clin Cardiol. 2010;33(5):280-288.

103. Rojas-Fernandez $\mathrm{CH}$, Cameron JC. Is statin-associated cognitive impairment clinically relevant? A narrative review and clinical recommendations. Ann Pharmacother. 2012;46(4):549-557.

104. Jukema JW, Cannon CP, de Craen AJ, Westendorp RG, Trompet S. The controversies of statin therapy: weighing the evidence. J Am Coll Cardiol. 2012;60(10):875-881.

105. Institute for the Study of Aging (ISOA). Lipitor as a treatment for Alzheimer's disease. In: ClinicalTrials.gov [website on the Internet]. Bethesda, MD: US National Library of Medicine; 2001 [updated November 8, 2006]. Available from: http://clinicaltrials.gov/ct2/show/ NCT00024531. NLM identifier: NCT00024531. Accessed September 30, 2012.

106. Pfizer. To evaluate the safety and effectiveness of atorvastatin plus a cholinesterase inhibitor in AD patients. In: Clinical Trials.gov [website on the Internet]. Bethesda, MD: US National Library of Medicine; 2005 [updated July 9, 2008]. Available from: http://clinicaltrials.gov/ ct2/show/NCT00151502. NLM identifier: NCT00151502. Accessed September 30, 2012.

107. National Institute on Aging (NIA). Cholesterol lowering agent to slow progression (CLASP) of Alzheimer's disease study. In: ClinicalTrials. gov [website on the Internet]. Bethesda, MD: US National Library of Medicine; 2003 [updated July 24, 2009]. Available from: http:// clinicaltrials.nlm.nih.gov/ct2/show/NCT00053599. NLM identifier: NCT00053599. Accessed September 30, 2012. 
Neuropsychiatric Disease and Treatment

Dovepress

\section{Publish your work in this journal}

Neuropsychiatric Disease and Treatment is an international, peerreviewed journal of clinical therapeutics and pharmacology focusing on concise rapid reporting of clinical or pre-clinical studies on a range of neuropsychiatric and neurological disorders. This journa is indexed on PubMed Central, the 'PsycINFO' database and CAS.

The manuscript management system is completely online and includes a very quick and fair peer-review system, which is all easy to use. Visit http://www.dovepress.com/testimonials.php to read real quotes from published authors.

\footnotetext{
Submit your manuscript here: http://www.dovepress.com/neuropsychiatric-disease-and-treatment-journal
} 